\title{
Association of insufficient physical activity with sarcopenia and sarcopenic obesity in individuals aged
} 50 years or more

\author{
Análise da associação da prática insuficiente \\ de atividade física com sarcopenia e obesidade \\ sarcopênica em indivíduos com idade \\ igual ou superior a 50 anos
}

\author{
Vanessa Ribeiro dos SANTOS ${ }^{1}$ \\ Monique Yndawe Castanho ARAUJO2 \\ Michel Rocha CARDOSO ${ }^{3}$ \\ Vitor Cabrera BATISTA ${ }^{3}$ \\ Diego Giulliano Destro CHRISTOFARO 1,2,3 \\ Luís Alberto GOBBO ${ }^{1,3}$
}

\section{A B S T R A C T}

\section{Objective}

To analyze the association of insufficient physical activity in different domains with sarcopenia or sarcopenic obesity in patients aged $\geq 50$ years.

\section{Methods}

The sample consisted of 770 males and females. Sarcopenia was diagnosed when the individual had: (1) low muscle mass and muscle strength; or (2) low walking speed and low muscle mass; sarcopenic obesity was diagnosed when individuals were at risk of obesity and sarcopenia. Muscle mass was given by a predictive equation, and then the muscle mass index (in $\mathrm{kg} / \mathrm{m}^{2}$ ) was given by muscle mass divided by height squared.

\footnotetext{
1 Universidade Estadual Paulista, Instituto de Biociências, Programa de Pós-Graduação em Ciências da Motricidade. Av. 24 A, 1515, Bela Vista, 13506-000, Rio Claro, SP, Brasil. Correspondência para/Correspondence to: LA GOBBO. E-mail: <luisgobbo@fct.unesp.br>.

2 Universidade Estadual Paulista, Faculdade de Ciências e Tecnologia, Programa de Pós-Graduação em Fisioterapia. Presidente Prudente, SP, Brasil.

${ }^{3}$ Universidade Estadual Paulista, Faculdade de Ciências e Tecnologia, Departamento de Educação Física. Presidente Prudente, SP, Brasil.
} 
Muscle strength, in $\mathrm{kg}$, was given by measuring handgrip strength with a digital dynamometer. The $4 \mathrm{~m}$ walk test evaluated walking sped. Low muscle mass, muscle strength, and walking speed were defined as the respective values below the 25 th percentile, and risk of obesity was defined as body mass index $\geq 25 \mathrm{~kg} / \mathrm{m}^{2}$.

\section{Results}

Habitual physical activity was investigated by a questionnaire. Insufficient leisure-time physical activity was associated with sarcopenia $(\mathrm{OR}=2.55 ; 95 \% \mathrm{Cl}=1.10-5.88)$. In addition, insufficient leisure-time physical activity $(\mathrm{OR}=4.75 ; 95 \% \mathrm{Cl}=1.64-13.72)$, leisure-time and commuting physical activities ( $\mathrm{OR}=2.49 ; 95 \% \mathrm{Cl}=1.02-6.11$, and habitual physical activity $(\mathrm{OR}=3.55 ; 95 \% \mathrm{Cl}=1.0-11.79)$ were associated with sarcopenic obesity.

\section{Conclusion}

Insufficient physical activity is associated with sarcopenia or sarcopenic obesity in the study individuals aged $\geq 50$ years.

Keywords: Anthropometry. Body composition. Health services. Motor activity. Muscle strength dynamometer.

\section{RE S U M O}

\section{Objetivo}

Analisar a associação entre a prática insuficiente de atividade física em diferentes domínios e a presença de sarcopenia ou obesidade sarcopênica em individuos com idade maior ou igual a 50 anos.

\section{Métodos}

A amostra foi constituída por 770 indivíduos de ambos os sexos. Para o diagnóstico da sarcopenia, considerou-se: (1) baixas massa e força muscular; ou (2) baixa velocidade de locomoção e baixa massa muscular; para o diagnóstico de obesidade sarcopênica, foram considerados aqueles com indicativo de risco para obesidade e sarcopenia. A massa muscular foi mensurada por meio de equação preditiva e, posteriormente, foi calculado o índice de massa muscular em $\mathrm{kg} / \mathrm{m}^{2}$ a partir da razão entre massa muscular e estatura. A força muscular foi estimada, em kg, por força de preensão manual através de um dinamômetro digital. O teste de caminhada de quatro metros foi utilizado para avaliar a velocidade de locomoção. Foram considerados com baixas massa muscular, força muscular e velocidade de locomoção os indivíduos com valores abaixo do percentil 25; já os indivíduos com indicativo de risco para obesidade foram aqueles com valores de índice de massa corporal igual ou superior a $25 \mathrm{~kg} / \mathrm{m}^{2}$. A prática de atividade física habitual foi avaliada por questionário autorreferido.

\section{Resultados}

A prática insuficiente de exercício físico no lazer associou-se à sarcopenic $(O R=2,55$; IC95\%=1, 10-5, 88). Além disso, a prática insuficiente de exercício físico no lazer (OR=4,75; IC95\%=1,64-13,72) e atividade física no lazer e locomoção $(O R=2,49 ; \quad I C 95 \%=1,02-6,11)$, bem como a atividade física habitual $(O R=3,55$; IC95\%=1,07-11,79) se associaram à obesidade sarcopênica.

\section{Conclusão}

A prática insuficiente de atividade física associou-se à sarcopenia ou à obesidade sarcopênica em individuos com idade maior ou igual a 50 anos na amostra investigada.

Palavras-chave: Antropometria. Composição Corporal. Serviços de saúde. Atividade motora. Dinamômetro de Força muscular.

\section{INTRODUCTION}

Low muscle mass associated with low muscle strength or poor motor performance is defined as sarcopenia [1], and when it is associated with excess body fat, it is called sarcopenic obesity [2].

Sarcopenia and sarcopenic obesity may reduce functional capacity, hindering the ability of older adults to perform Activities of Daily Living $(A D L)$. Moreover, they are risk factors for cardiometabolic diseases [3,4], falls [5], frailty [6], and death $[7,8]$.

Regular physical activity helps to maintain or even increase muscle mass and strength $[9,10]$, and reduce body fat [9] and consequently, improve motor performance [11]. In this sense, physical activity may contribute to the prevention and 
treatment of sarcopenia and sacorpenic obesity in older adults [12].

Recently, some studies have reported associations of insufficient physical activity with sarcopenia and sarcopenic obesity in older adults [13-16], but these studies did not investigate physical activity by domain and the relationship of said domains with sarcopenia and sarcopenic obesity, which would allow the adoption of preventive health measures, such as a knowingly beneficial physical activity of a specific domain. These aspects should be investigated in older adults, as their population is increasing rapidly and growing age reduces the level of physical activity and increases the risk of chronic diseases. Hence, the objective of this study was to analyze whether insufficient physical activity is associated with sarcopenia or sarcopenic obesity in individuals aged 50 years or more.

\section{METHOD S}

This cross-sectional study used the data obtained in the initial assessment of two distinct cohorts with similar characteristics (study variables, measurement instruments, and researchers). The first study, conducted from September 2013 to September 2015, aimed to investigate the association of physical activity with outpatient, secondary, and tertiary expenditures with the Unified Healthcare System (SUS) patients from Presidente Prudente (SP), a city located in the Southeast region of Brazil. The study included individuals aged 50 years or more registered and treated at two Primary Healthcare Units (PHU) referred by the Municipal Department of Health. The patients were invited to participate and assessed while they waited for their appointment or after the appointment. The assessments were performed in the morning in September and October of 2013, and the researchers remained in the PHUs during this period to invite all patients who met the inclusion criteria. Thus, 476 individuals aged 50 to 88 years were assessed.
The second study, conducted from January 2015 to April 2017, aims to investigate the influence of physical activity on sarcopenia, sarcopenic obesity, dysmobility syndrome, and functional disability in older adults. The study included individuals aged 60 years or older who were invited to participate in the study by the local media and at municipal locations highly frequented by older adults. The first data collection occurred from January to April 2015 at the Centro de Estudos e Laboratório de Avaliação e Prescrição de Atividade Motora (Celapam, Study Center and Laboratory of Motor Activity Assessment and Prescription) of the Department of Physical Education of Faculty of Science and Technology of the Universidade Estadual Paulista (Unip) in Presidente Prudente (SP). A total of 294 individuals aged 60 to 97 years were assessed.

The participants who accepted the invitation for the projects signed an individual informed consent form. All Protocols were reviewed and approved by the Research Ethics Committee of Unip (Protocol $n^{\circ}$ 241.291/2013 and $n^{\circ}$ 980.458/2015).

Body weight was measured by the electronic scale Filizola ${ }^{\circledR}$ Antropométrica (São Paulo, SP, Brazil), with maximum capacity of $180 \mathrm{~kg}$ and accuracy of $0.1 \mathrm{~kg}$, and height, by the wall-mounted stadiometer Sanny ${ }^{\circledR}$, Standard model (São Bernardo do Campo, SP, Brazil), with length of $2.20 \mathrm{~m}$ and graduation of $0.1 \mathrm{~cm}$. The measurements were performed as recommended by Freitas Jr et al. [17]. The Body Mass Index (BMI) was then calculated by dividing the body weight by the square of the height $\left(\mathrm{kg} / \mathrm{m}^{2}\right)$.

The prevalence of chronic noncommunicable diseases was determined by the summarized selfreported diseases of the Standard Health Questionnaire for Washington State, which consists of a closed survey that investigates the presence of chronic diseases distributed into three groups: metabolic, cardiovascular, and osteoarticular. The main diseases investigated are hypertension, diabetes, dyslipidemia, thyroid 
disorders, osteoporosis, arthritis/arthrosis, and spinal diseases [18].

Muscle mass was given by the predictive equation [19] described below: $(\mathrm{kg})=0.244 \mathrm{x}$ body weight $(\mathrm{kg})+7.8 \times$ height $(\mathrm{m})-0.098 \times$ age (years) $+6.6 \times$ gender + ethnicity -3.3 , where: gender $=1$ for men and 0 for women; ethnicity $=-1.2$ for Asians, 0 for whites, and 1.4 for blacks.

The equation has been validated for the Brazilian population and presented high correlation with Dual-Energy X-Ray Absorptiometry (Dexa), ( $r=0.86$ for men and $r=0.90$ for women, respectively, $p<0.05)$. Agreement between Dexa and the predictive equation to find individuals with low muscle mass is strong $(k=0.74 ; p<0.001)$ and has high specificity (89\%) and sensitivity (86\%) [20].

Later, the muscle mass index was calculated by dividing the muscle mass in $\mathrm{kg}$ by the square of the height in meters $\left(\mathrm{kg} / \mathrm{m}^{2}\right)$.

Muscle strength was estimated in $\mathrm{kg}$ by measuring the handgrip strength with a digital dynamometer of the brand Camry, model EH101 (Guangdong, China). The test was conducted twice while the individuals sat on an armless chair, shoulders adducted, and elbow of the dominant arm flexed $90^{\circ}$, with the forearm and wrist in neutral position. The older adults were instructed to press the dynamometer as hard as they could twice, at a one-minute interval. The highest value was recorded.

Walking speed was determined by the 4-meter walk test [21]. The older adults were asked to walk naturally, as they were walking at home, and the highest speed $(\mathrm{m} / \mathrm{s})$ of two walks was recorded.

Low muscle mass, muscle strength, and walking speed were defined as those below the 25th percentile for each variable by gender (men $=9.66 \mathrm{~kg} / \mathrm{m}^{2}, 29.50 \mathrm{~kg}$, and $0.86 \mathrm{~m} / \mathrm{s}$; women: $8.14 \mathrm{~kg} / \mathrm{m}^{2}, 18.00 \mathrm{~kg}$, and $0.81 \mathrm{~m} / \mathrm{s}$, respectively).

Sarcopenia was diagnosed using the criteria recommended by Cruz-Jentoft et al. [1], namely (1) low muscle mass and muscle strength; or (2) low muscle mass and walking speed.

Individuals were considered at risk of obesity when they BMI $\geq 25 \mathrm{~kg} / \mathrm{m}^{2}$ [22]. Individuals with the two conditions (obesity and sarcopenia) were diagnosed with sarcopenic obesity [2].

Information related to Habitual Physical Activity (HPA) was collected by interview using the questionnaire developed by Baecke et al. [23]. This instrument has been validated for Brazilians aged 50 years or more by Florindo et al. [24].

The instrument consists of 16 questions and investigates the level of HPA in three domains: occupational (type of occupation and activities performed during work); leisure-time physical activity (practice of regular physical exercises); and leisure-time and commuting activities (watch TV, walk, or bike during leisure time or when commuting).

The level of physical activity in each domain was calculated and the sum of the scores of each domain provide the HPA score. HPA was classified by the formula proposed by Baecke et al. [23]. The level of physical activity of the sample was divided into quartiles for the three study domains: (1) occupational; (2) leisure-time physical activity; (3) leisure-time and commuting physical activity; and 4) total score (HPA).

Individuals in the fourth quartile of each domain [occupational (3.00); leisure-time physical activity (2.50); leisure-time and commuting physical activity (2.50)] and HPA (7.37) were considered sufficiently active. Those in the first, second, and third quartiles of each domain were classified as insufficiently active.

Descriptive statistics was expressed as relative frequency. The association of the percentages of each variable with the presence or absence of sarcopenia or sarcopenic obesity was investigated by the Chi-square test. This same test also verified the association of the scores in the different physical activity domains with sarcopenia and sarcopenic obesity. All variables with $p<0.20$ in the Chi-square test were selected 
for the forward stepwise binary multiple logistic regression models. The data were treated by the statistical software Statistical Package for the Social Sciences (SPSS Inc, Chicago, Illinois, United Srates), version 17.0, and the level of significance was established at $5 \%$. This study used a confidence interval of $95 \%$.

\section{RES U L T S}

The 770 participants, 225 men (29\%) and 545 women $(71 \%)$, were aged 50 to 97 years $(65 \pm 9$ years). The mean age of men ( $67 \pm 9$ years) was significantly higher than that of women $(65 \pm 9$ years, $p \leq 0.001)$.

Table 1 shows the prevalence of sarcopenia and sarccopenic obsity for the total sample and by gender, and in each gender, by level of physical activity. The prevalences of sarcopenia and sarcopenic obesity did not differ significantly by gender.

The prevalences of both conditions was lower in sufficiently physically active women, especially sarcopenia $(p<0.05)$.

Table 2 shows the general characteristics of the sample according to the presence of the two study conditions. Most individuals with sarcopenia were aged 70 years or more, had lower income, higher prevalence of hypertension $(p<0.05)$, and low muscle mass and walking speed $(p \leq 0.001)$. Most individuals with sarcopenic obesity were also aged 70 years or more, lower income, low muscle strength and walking speed $(p \leq 0.001)$, and a higher prevalence of osteoporosis $(p<0.05)$.

Figure 1 shows the percentage of physically active individuals in each of the study domains and HPA by gender. The percentage of women who were occupationally active was higher than that of men $(p \leq 0.001)$. On the other hand, the percentage of physically active men during leisure time or commuting was higher than that of women $(p \leq 0.001)$. Leisure-time physical activity and HPA did not differ by gender.

Table 3 shows the association of level of physical activity with sarcopenia and sarcopenic obesity. Insufficient leisure-time physical activity was associated with sarcopenia and sarcopenic obesity, and insufficient physical activity while commuting and in the sum of all physical activity domains was associated with sarcopenic obsity.

Table 4 shows the multiple logistic regression models of the association of physical activity with sarcopenia and sarcopenic obesity. Insufficient leisure-time physical activity was

Table 1. Prevalence of the study conditions by gender and Habitual Physical Activity.

\begin{tabular}{|c|c|c|c|c|c|c|c|c|}
\hline \multirow{3}{*}{ Habitual physical activity } & \multicolumn{4}{|c|}{ Sarcopenia } & \multicolumn{4}{|c|}{ Sarcopenic obesity } \\
\hline & \multicolumn{2}{|c|}{ Absent } & \multicolumn{2}{|c|}{ Present } & \multicolumn{2}{|c|}{ Absent } & \multicolumn{2}{|c|}{ Present } \\
\hline & $\mathrm{n}$ & $\%$ & $\mathrm{n}$ & $\%$ & $n$ & $\%$ & $n$ & $\%$ \\
\hline Total & 729 & 94.3 & 41 & 5.3 & 732 & 95.1 & 38 & 4.9 \\
\hline Males & 211 & 93.8 & 14 & 6.3 & 514 & 96.9 & 7 & 3.1 \\
\hline Females & 518 & 95.0 & 27 & 5.0 & 218 & 94.3 & 31 & 5.7 \\
\hline \multirow[t]{2}{*}{$-\chi^{2}(p)$} & \multicolumn{4}{|c|}{$0.508(0.476)$} & \multicolumn{4}{|c|}{$2.254(0.133)$} \\
\hline & \multicolumn{4}{|c|}{ Sarcopenia $(n=41)$} & \multicolumn{4}{|c|}{ Sarcopenic obesity $(n=38)$} \\
\hline \multirow[t]{2}{*}{ Habitual physical activity } & \multicolumn{2}{|c|}{ Sufficient } & \multicolumn{2}{|c|}{ Insufficient } & \multicolumn{2}{|c|}{ Sufficient } & \multicolumn{2}{|c|}{ Insufficient } \\
\hline & $n$ & $\%$ & $n$ & $\%$ & $n$ & $\%$ & $n$ & $\%$ \\
\hline Males & 3 & 21.4 & 11 & 78.6 & 0 & 0.0 & 7 & 100.0 \\
\hline$-\chi^{2}(p)$ & \multicolumn{4}{|c|}{$0.209(0.647)$} & & & & \\
\hline Females & 2 & 7.4 & 27 & 92.6 & 3 & 9.7 & 28 & 90.3 \\
\hline$-\chi^{2}(p)$ & \multicolumn{4}{|c|}{$4.596(0.032)$} & \multicolumn{4}{|c|}{$4.018(0.045)$} \\
\hline
\end{tabular}


Table 2. General characteristics of the study sample by the presence of the study conditions.

\begin{tabular}{|c|c|c|c|c|c|c|c|c|c|c|}
\hline \multirow{3}{*}{ Characteristics } & \multicolumn{4}{|c|}{ Sarcopenia $(n=41)$} & \multirow{3}{*}{$p$} & \multicolumn{4}{|c|}{ Sarcopenic obesity $(n=38)$} & \multirow{3}{*}{$p$} \\
\hline & \multicolumn{2}{|c|}{ No } & \multicolumn{2}{|c|}{ Yes } & & \multicolumn{2}{|c|}{ No } & \multicolumn{2}{|c|}{ Yes } & \\
\hline & $n$ & $\%$ & $n$ & $\%$ & & $\mathrm{n}$ & $\%$ & $n$ & $\%$ & \\
\hline \multicolumn{11}{|l|}{ Age years } \\
\hline $50-59$ & 214 & 29.3 & 9 & 21.9 & 0.017 & 216 & 29.5 & 7 & 18.4 & $\leq 0.001$ \\
\hline $60-69$ & 303 & 41.6 & 11 & 26.8 & & 307 & 41.9 & 7 & 18.4 & \\
\hline 70 & 212 & 29.1 & 21 & 51.2 & & 209 & 28.5 & 24 & 63.1 & \\
\hline \multicolumn{11}{|l|}{ Ethnicity } \\
\hline White & 495 & 67.9 & 29 & 70.7 & 0.263 & 495 & 67.6 & 30 & 78.9 & 0.324 \\
\hline Black & 208 & 28.5 & 8 & 19.5 & & 210 & 28.7 & 6 & 15.8 & \\
\hline Asian & 26 & 3.6 & 3 & 7.3 & & 27 & 3.7 & 2 & 5.3 & \\
\hline \multicolumn{11}{|l|}{ Income } \\
\hline Higher & 257 & 35.2 & 7 & 17.1 & 0.002 & 215 & 29.4 & 5 & 13.1 & $\leq 0.001$ \\
\hline Medium & 259 & 35.5 & 12 & 29.3 & & 258 & 35.2 & 13 & 34.2 & \\
\hline Lower & 213 & 29.2 & 22 & 53.6 & & 259 & 35.4 & 20 & 52.6 & \\
\hline \multicolumn{11}{|l|}{ Hypertension } \\
\hline Yes & 462 & 63.4 & 19 & 46.3 & 0.028 & 453 & 61.9 & 28 & 73.7 & 0.143 \\
\hline \multicolumn{11}{|l|}{ Dyslipidemia } \\
\hline Yes & 218 & 29.9 & 10 & 24.4 & 0.452 & 732 & 29.6 & 11 & 28.9 & 0.927 \\
\hline \multicolumn{11}{|l|}{ Diabetes } \\
\hline Yes & 150 & 20.6 & 6 & 14.6 & 0.355 & 146 & 19.9 & 10 & 26.3 & 0.343 \\
\hline \multicolumn{11}{|l|}{ Thyroid disorders } \\
\hline Yes & 83 & 11.4 & 7 & 17.1 & 0.270 & 87 & 11.9 & 3 & 7.9 & 0.456 \\
\hline \multicolumn{11}{|c|}{ Myocardial infarction } \\
\hline Yes & 38 & 5.2 & 1 & 2.4 & 0.431 & 37 & 5.0 & 10 & 5.3 & 0.954 \\
\hline \multicolumn{11}{|l|}{ Osteoporosis } \\
\hline Yes & 114 & 15.6 & 3 & 7.3 & 0.149 & 105 & 14.3 & 12 & 35.6 & 0.004 \\
\hline \multicolumn{11}{|l|}{ Arthritis/arthrosis } \\
\hline Yes & 344 & 47.2 & 14 & 34.1 & 0.103 & 338 & 46.2 & 20 & 52.6 & 0.437 \\
\hline \multicolumn{11}{|c|}{ Muscle strength $(\mathrm{kg})$} \\
\hline Low & 156 & 21.4 & 33 & 80.5 & $\leq 0.001$ & 164 & 22.4 & 25 & 65.8 & $\leq 0.001$ \\
\hline \multicolumn{11}{|c|}{ Walking speed $(\mathrm{m} / \mathrm{s})$} \\
\hline Low & 172 & 23.6 & 19 & 46.3 & $\leq 0.001$ & 162 & 22.1 & 29 & 76.3 & $\leq 0.001$ \\
\hline
\end{tabular}

Note: BMI: Body Mass Index.

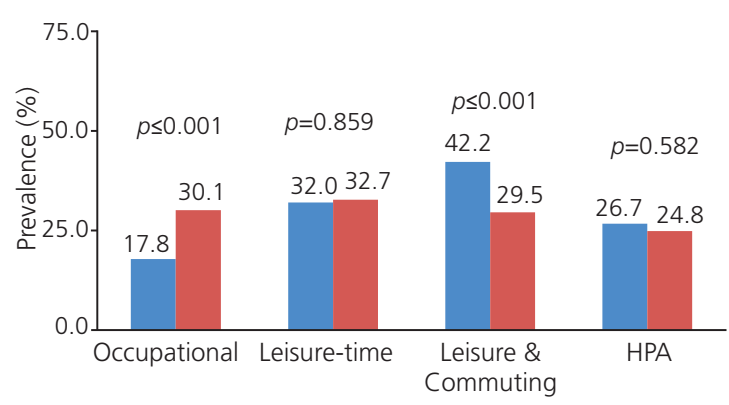

Physical activity domains

Men Women

Figure 1. Percentage of physically active individuals according to physical activity domains and gender.

Note: HPA: Habitual Physical Activity. associated with sarcopenia. Additionally, insufficient physical activity in the domains 'leisure-time physical activity, leisure-time physical activity and commuting, and HPA were associated with sarcopenic obesity.

\section{I S C US S I O N}

The main findings of this study was that after assessing the level of physical activity in different domains (occupational, leisure-time, and commuting) and globally, insufficient physical 
Table 3. Association of physical activity with sarcopenia and sarcopenic obesity in individuals aged 50 years or more.

\begin{tabular}{|c|c|c|c|c|c|c|}
\hline \multirow{2}{*}{ Physical activity } & \multicolumn{3}{|c|}{ Sarcopenia } & \multicolumn{3}{|c|}{ Sarcopenic obesity } \\
\hline & $\mathrm{n}$ & $\%$ & OR $(95 \% \mathrm{Cl})$ & $\mathrm{n}$ & $\%$ & OR $(95 \% \mathrm{Cl})$ \\
\hline \multicolumn{7}{|l|}{ Occupational } \\
\hline Sufficient & 10 & 24.4 & 1.00 & 6 & 15.8 & 1.00 \\
\hline Insufficient & 31 & 75.6 & $2.34(0.94-5.95)$ & 32 & 84.2 & $1.98(0.81-4.80)$ \\
\hline \multicolumn{7}{|c|}{ Leisure-time physical activity } \\
\hline Sufficient & 7 & 17.1 & 1.00 & 4 & 10.5 & 1.00 \\
\hline Insufficient & 34 & 82.9 & $2.43(1.06-5.56)$ & 34 & 89.5 & $4.30(1.51-12.26)$ \\
\hline \multicolumn{7}{|c|}{ Leisure and commuting } \\
\hline Sufficient & 18 & 43.9 & 1.00 & 6 & 15.8 & 1.00 \\
\hline Insufficient & 23 & 56.1 & $0.62(0.33-1.17)$ & 32 & 84.2 & $2.77(1.14-6.70)$ \\
\hline \multicolumn{7}{|c|}{ Habitual physical activity } \\
\hline Sufficient & 5 & 12.2 & 1.00 & 3 & 7.9 & 1.00 \\
\hline Insufficient & 36 & 87.8 & $2.54(0.98-6.56)$ & 35 & 92.1 & $4.15(1.26-13.64)$ \\
\hline
\end{tabular}

Note: OR: Odds Ratio; 95\% Cl: 95\% Confidence Interval.

Table 4. Multiple regression models for the association of physical activity in each domain and total score with sarcopenia and sarcopenic obesity in individuals aged 50 years or more.

\begin{tabular}{|c|c|c|}
\hline \multirow{2}{*}{ Physical activity } & Sarcopenia & Sarcopenic obesity \\
\hline & AdjOR $(95 \% \mathrm{Cl})$ & AdjOR $(95 \% \mathrm{Cl})$ \\
\hline \multicolumn{3}{|l|}{ Occupational } \\
\hline Sufficient & 1.00 & 1.00 \\
\hline Insufficient & $0.89(0.42-1.91)$ & $1.62(0.64-4.07)$ \\
\hline \multicolumn{3}{|c|}{ Leisure-time physical activity } \\
\hline Sufficient & 1.00 & 1.00 \\
\hline Insufficient & $2.63(1.06-6.49)$ & $3.97(1.35-11.64)$ \\
\hline \multicolumn{3}{|c|}{ Leisure and commuting } \\
\hline Sufficient & 1.00 & 1.00 \\
\hline Insufficient & $0.60(0.31-1.16)$ & $2.50(1.00-6.25)$ \\
\hline \multicolumn{3}{|c|}{ Habitual physical activity } \\
\hline Sufficient & 1.00 & 1.00 \\
\hline Insufficient & $2.38(0.90-6.28)$ & $3.71(1.10-12.46)$ \\
\hline
\end{tabular}

Notes: For sarcopenia, the models were adjusted for income: higher, medium, and lower; age groups: 50-59, 60-69, and $\geq 70$ years; and hypertension, for sarcopenic obesity, the models were adjusted for age group: 50-59, 60-69, and $\geq 70$ years; income: higher, medium, and lower; and osteoporosis. AdjOR: Adjusted Odds Ratio; 95\%Cl: 95\% Confidence Interval.

activity, especially during leisure time, is associated with sarcopenia or sarcopenic obesity.

The prevalence of sarcopenia in the study sample was similar for males and females, but it differed from the prevalences reported by other studies, which found differences by gender, with higher prevalences in men $[25,26]$. The prevalence of sarcopenic obesity was similar to that of sarcopenia, contrary to what has been reported by other studies $[3,16]$, which found higher prevalences of sarcopenia. Moreover, the prevalences of sarcopenic obesity in males and females were similar, also differing from other reports $[27,28]$, which found a higher prevalence of sarcopenic obesity in women. In fact, the prevalences and intergender differences may vary according to diagnostic criteria and cut-off points.

Sufficiently active women had lower prevalences of sarcopenia and sarcopenic obesity $(p<0.05)$. Ryu et al. [16] also found an inverse 
association between level of physical activity and sarcopenic obesity, not between level of physical activity and sarcopenia in women. Unlike Ryu et al. [16], the present study did not find an association between insufficient physical activity and sarcopenia in men. It was also not possible to investigate whether insufficient physical activity was associated with sarcopenie obesity because none of the sufficiently active men had sarcopenic obesity.

Women perform more household chores confirmed by the present study, and men are more active in other domains. Men also tend to get more involved in sports [29-31]. The study men were significantly more active in the domain 'leisure time and commuting, Nevertheless, neither leisure-time physical activity nor HPA differed by gender. Intergender differences may vary according to the characteristics of the sample (income, education level, and access to areas appropriate for physical activities) [29].

Insufficient leisure-time physical activity was associated with sarcopenia in the study sample. One of the possible explanations is the fact that leisure-time physical activities are related to sports, supervised training in gyms, and anaerobic exercises, which more effectively prevent and treat sarcopenia [12]. Such observation reinforces the importance of also investigating whether the sarcopenia is associated with physical activity in different domains. Thus, the study findings may complement the results of other studies [13-16] that did not investigate this association.

Physical activity may minimize the effects of muscle apoptosis, which reduces the number and size of muscle fibers [12,32], and helps the musculoskeletal function, improving motor function [11], ability to carry out activities of daily living, and consequently, the quality of life of older adults [33].

Insufficient physical activity was associated with sarcopenic obsity in two domains, leisuretime physical activity and leisure-time physical activity \& commuting, and in the total score, which represents the total habitual physical activity. Similar results were found by Ryu et al. [16] in older South Koreans of both genders. Regular physical activity, especially aerobic activity, reduces body fat, which inhibits the synthesis of pro-inflammatory cytokines, such as Tumor Necrosis Factor- $\alpha$ (TNF- $\alpha$ ) and Interleukin 6 (IL-6), which may decrease physical functioning because of their catabolic effect on muscles as these substances increase myofibrillar protein degradation and reduce protein synthesis [32].

Muscle also has endocrine function and produces cytokines, like IL-6, during physical activity. These substances are called myokines and may influence metabolism in other organs and tissues, but in this case they have antiinflammatory action [34]. This evidence reinforces the importance of physical activity for the prevention of sarcopenia and sacopenie obesity.

The study limitations include the sample, which is not representative of the population, so the results should not be generalized, the study cross-sectional design does not allow the establishment of a cause and effect relationship, the use of BMI and the cut-off point of $25 \mathrm{~kg} / \mathrm{m}^{2}$ to diagnose obesity, and the use of percentilebased cut-off points to classify muscle mass, muscle strength, and walking speed status. However, the literature has a gab regarding studies that aimed to verify these aspects in the Brazilian population. Another factor would be the subjective analysis of physical activity, but the use of more accurate instruments for measuring physical activity, such as accelerometer, is difficult in epidemiological studies. The study strengths include the assessment of people treated by primary healthcare units and the search for information that will allow an assiduous development of strategies to enable the primary prevention of sarcopenia, epidemiological investigation of sarcopenic obesity, and the association between sarcopenic obesity and different physical activity domains. 
In conclusion, insufficient physical activity was associated with sarcopenia and sarcopenic obesity in the study sample of individuals aged 50 years or more. Preventive measures, such as lifelong practice of physical activity, may contribute to the maintenance of muscle mass and strength, and to reduce the occurrence of sarcopenia and sarcopenic obesity in older adults.

\section{CONTRIBUTORS}

VR SANTOS obtained the subjects and data, analyzed and interpreted the results, and prepared, wrote, and reviewed the manuscript. MYC ARAUJO, MR CARDOSO, VC BATISTA and DGD CHRISTOFARO, LA GOBBO conceived and designed the study, obtained the subjects and data, analyzed and interpreted the data, and prepared and reviewed the manuscript.

\section{REFERENCES}

1. Cruz-Jentoft AJ, Baeyens JP, Bauer JM, Boirie Y, Cederholm T, Landi F, et al. Sarcopenia: European consensus on definition and diagnosis: Report of the European Working Group on Sarcopenia in older people. Age Ageing. 2010;39(4):412-23. https://doi.org/10.1093/ageing/afq034

2. Zamboni M, Mazzali G, Fantin F, Rossi A, Di Francesco V. Sarcopenic obesity: A new category of obesity in the elderly. Nutr Metab Cardiovasc Dis. 2008;18(5):388-95. https://doi.org/10.1016/ j.numecd.2007.10.002

3. Baek SJ, Nam GE, Han KD, Choi SW, Jung SW, Bok $A R$, et al. Sarcopenia and sarcopenic obesity and their association with dyslipidemia in Korean elderly men: The 2008-2010 Korea National Health and Nutrition Examination Survey. J Endocrinol Invest. 2014;37(3):247-60. https://doi.org/10.1007/s4 0618-013-0011-3

4. Han K, Park YM, Kwon HS, Ko SH, Lee SH, Yim $\mathrm{HW}$, et al. Sarcopenia as a determinant of blood pressure in older Koreans: Findings from the Korea National Health and Nutrition Examination Surveys (KNHANES) 2008-2010. PLoS One. 2014;9(1): e86902. https://doi.org/10.1371/journal.pone. 0086902

5. Woo N, Kim SH. Sarcopenia influences fall-related injuries in community-dwelling older adults. Geriatr Nurs. 2014;35(4):279:82. https://doi.org/10.1016/ j.gerinurse.2014.03.001
6. Cawthon PM, Peters KW, Shardell MD, McLean RR, Dam TT, Kenny AM, et al. Cutpoints for low appendicular lean mass that identify older adults with clinically significant weakness. J Gerontol A Biol Sci Med Sci. 2014;69(5):567-75. https://doi. org/10.1093/gerona/glu023

7. Kim JH, Lim S, Choi SH, Kim KM, Yoon JW, Kim $\mathrm{KW}$, et al. Sarcopenia: An independent predictor of mortality in community-dwelling older Korean men. J Gerontol A Biol Sci Med Sci. 2014;69(10): 1244-52. https://doi.org/10.1093/gerona/glu050

8. Atkins $J$, Whincup PH, Morris RW, Lennon LT, Papacosta O, Wannamethee SG. Sarcopenic obesity and risk of cardiovascular disease and mortality: A population-based cohort study of older men. J Am Geriatr Soc. 2014;62(2):253-60. https://doi.org/ 10.1111/jgs. 12652

9. Bann D, Kuh D, Wills AK, Adams J, Brage S, Cooper R. Physical activity across adulthood in relation to fat and lean body mass in early old age: Findings from the medical research council national survey of health and development, 1946-2010. Am J Epidemiol. 2014;179(10):1197-207. https://doi. org/10.1093/aje/kwu033

10. Dodds R, Kuh D, Aihie Sayer A, Cooper R. Physical activity levels across adult life and grip strength in early old age: Updating findings from a British birth cohort. Age Ageing. 2013; 42(6):794-8. https:// doi.org/10.1093/ageing/aft124

11. Martin HJ, Syddall HE, Dennison EM, Cooper C, Sayer AA. Relationship between customary physical activity, muscle strength and physical performance in older men and women: Findings from the Hertfordshire Cohort Study. Age Ageing. 2008;37(5):589-93. https://doi.org/10.1093/ ageing/afn148

12. Landi F, Marzetti E, Martone AM, Bernabei R, Onder G. Exercise as a remedy for sarcopenia. Curr Opin Clin Nutr Metab Care. 2014;17(1):25-31. https:// doi.org/10.1097/MC0.0000000000000018

13. Park H, Park S, Shephard RJ, Aoyagi Y. Yearlong physical activity and sarcopenia in older adults: The Nakanojo Study. Eur J Appl Physiol. 2010;109(5): 953-61. https://doi.org/10.1007/s00421-010-14 24-8

14. Kim SH, Kim TH, Hwang HJ. The relationship of physical activity (PA) and walking with sarcopenia in Korean males aged 60 years and older using the Fourth Korean National Health and Nutrition Examination Survey (KNHANES IV-2, 3), 2008-2009. Arch Gerontol Geriatr. 2013;56(3):472-7. http:// dx.doi.org/10.1016/j.archger.2012.12.009

15. Shephard RJ, Park H, Park S, Aoyagi Y. Objectively measured physical activity and progressive loss of lean tissue in older Japanese adults: Longitudinal 
data from the Nakanojo study. J Am Geriatr Soc. 2013; 61(11):1887-93. https://doi.org/10.1111/ jgs. 12505

16. Ryu M, Jo J, Lee Y, Chung YS, Kim KM, Baek WC. Association of physical activity with sarcopenia and sarcopenic obesity in community-dwelling older adults: the Fourth Korea National Health and Nutrition Examination Survey. Age Ageing. 2013;42(6):734-40. https://doi.org/10.1093/ ageing/aft063

17. Freitas Junior IF, Bueno DR, Buonani C, Codogno JS, Conterato I, Fernandes RA, et al. Padronização de técnicas antropométricas. Presidente Prudente: Cultura Acadêmica; 2009.

18. Washington State Health Insurance Pool. Standard Health Questionnaire for Washington state. Washington (DC): WSHIP; 2005.

19. Lee RC, Wang Z, Heo M, Ross R, Janssen I, Heymsfield SB. Total-body skeletal muscle mass: Development and cross-validation of anthropometric prediction models. Am J Clin Nutr. 2000;72(3):796-803.

20. Rech CR, Dellagrana RA, Marucci MFN, Petroski EL. Validity of anthropometric equations for the estimation of muscle mass in elderly. Braz J Kineant. 2012;14(1):23-31. https://doi.org/10.5007/1980-0 $037.2012 \mathrm{v} 14 \mathrm{n} 1 \mathrm{p} 23$

21. Guralnik JM, Simonsick EM, Ferrucci L, Glynn R.J, Berkman LF, Blazer DG, et al. A short physical performance battery assessing lower extremity function: Association with self-reported disability and prediction of mortality and nursing home admission. J Gerontol. 1994;49(2):M85-94.

22. World Health Organization. Obesity: Preventing and managing the global epidemic: Report of a WHO consultation on obesity. Geneva: WHO; 1998.

23. Baecke JA, Burema J, Frijters JE. A short questionnaire for the measurement of habitual physical activity in epidemiological studies. Am J Clin Nutr. 1982;36(5):936-42.

24. Florindo AA, Latorre MRDO, Jaime PC, Tanaka T, Zerbini CAF. Methodology to evaluation the habitual physical activity in men aged 50 years or more. Rev Saúde Pública. 2004;38(2):307-14. https://dx.doi.org/10.1590/S0034-8910200 4000200022

25. Janssen I, Baumgartner RN, Ross R, Rosenberg IH, Roubenoff R. Skeletal muscle cutpoints associated with elevated physical disability risk in older men and women. Am J Epidemiol. 2004;159(4):413-21.
26. Abe T, Thiebaud RS, Loenneke JP, Loftin M, Fukunaga T. Prevalence of site-specific thigh sarcopenia in Japanese men and women. Age (Dordr). 2014;36(1):417-26. https://doi.org/ 10.1007/s11357-013-9539-6

27. Kim TN, Park MS, Lim KI, Choi HY, Yang SJ, Yoo HJ, et al. Relationships between sarcopenic obesity and insulin resistance, inflammation, and vitamin D status: The Korean Sarcopenic Obesity Study. Clin Endocrinol. 2013;78(4):525-32. https://doi.org/ 10.1111/j.1365-2265.2012.04433.x

28. Hwang B, Lim JY, Lee J, Choi NK, Ahn YO, Park BJ. Prevalence rate and associated factors of sarcopenic obesity in Korean elderly population. J Korean Med Sci. 2012;27(7):748-55. https://doi.org/10.3346/ jkms.2012.27.7.748

29. Florindo AA, Hallal PC, Moura EC, Malta DC. Practice of physical activities and associated factors in adults, Brazil, 2006. Rep Public Health. 2009;43(Supl.2):65-73. https://doi.org/10.1590/ S0034-89102009000900009

30. Moschny A, Platen P, Klaassen-Mielke R, Trampisch $U$, Hinrichs T. Physical activity patterns in older men and women in Germany: A cross-sectional study. BMC Public Health. 2011;11:559. https://doi.org/ 10.1186/1471-2458-11-559

31. Mourao ARC, Novais FV, Andreoni S, Ramos LR. Atividade física de idosos relacionada ao transporte e lazer, Maceió, Brasil. Rev Saúde Pública. 2013;47(6):1112-22. https://doi.org/10.1590/ S0034-8910.2013047004904

32. Montero-Fernández N, Serra Rexach JA. Role of exercise on sarcopenia in the elderly. Eur J Rehabil Med. 2013;49(1):131-43.

33. Haskell WL, Lee IM, Pate RR, Powell KE, Blair SN, Franklin BA, et al. Physical activity and public health: Updated recommendation for adults from the American College of Sports Medicine and the American Heart Association. Circulation. 2007; 116(9):1081-93.

34. Pedersen BK, Febbraio MA. Muscles, exercise and obesity: Skeletal muscle as a secretory organ. Nat Rev Endocrinol. 2012;8(8):457-65. https://doi.org/ 10.1038/nrendo.2012.49

Received: June 20, 2016

Final version: September 22, 2016

Approved: November 8, 2016 